\title{
Influence of Biofield Treatment on Physical and Structural Characteristics of Barium Oxide and Zinc Sulfide
}

Mahendra Kumar Trivedi ${ }^{1}$, Rama Mohan Tallapragada ${ }^{1}$, Alice Branton ${ }^{1}$, Dahryn Trivedi ${ }^{1}$, Omprakash Latiyal ${ }^{2}$ and Snehasis Jana ${ }^{2 *}$

${ }^{1}$ Trivedi Global Inc., 10624 S Eastern Avenue Suite A-969, Henderson, NV 89052, USA

${ }^{2}$ Trivedi Science Research Laboratory Pvt. Ltd., Hall-A, Chinar Mega Mall, Chinar Fortune City, Hoshangabad Rd., Bhopal- 462026 Madhya Pradesh, India

\begin{abstract}
Barium oxide $(\mathrm{BaO})$ and zinc sulfide $(\mathrm{ZnS})$ are well known for their applications in electrical, optical and chemical industries. The present study was aimed to evaluate the impact of biofield treatment on the structural and physical properties of $\mathrm{BaO}$ and $\mathrm{ZnS}$ powder. The study was carried out in two groups, one was set to control, and another group was subjected to Mr. Trivedi's biofield treatment. Control and treated samples of $\mathrm{BaO}$ and $\mathrm{ZnS}$ were analyzed using X-ray diffraction (XRD), Fourier transform infrared spectroscopy (FT-IR), and surface area analyzer. XRD data showed that lattice parameter and unit cell volume of $\mathrm{BaO}$ powder were reduced upto $0.42 \%$ and $1.26 \%$, respectively as compared to control. Whereas, density of treated $\mathrm{BaO}$ was increased upto $1.27 \%$ as compared to control. Besides, the unit cell volume was changed in treated $\mathrm{ZnS}$ from -0.55 to $0.24 \%$ as compared to control that led to change in density from -0.24 to $0.55 \%$ after biofield treatment. However, the crystallite size was substantially increased upto $40.5 \%$ and $71.4 \%$ in treated $\mathrm{BaO}$ and $\mathrm{ZnS}$, respectively as compared to control. FT-IR data exhibited that absorption peaks at wavenumber $862 / \mathrm{cm}$ (control) was shifted to $858 / \mathrm{cm}$ in treated $\mathrm{BaO}$. Upward shifting of absorption peaks corresponding to $\mathrm{Zn}-\mathrm{S}$ stretching bond was observed in treated $(617 / \mathrm{cm})$ as compared to control $(592 / \mathrm{cm})$. Furthermore, surface area result showed that it was reduced by $4.32 \%$ and $2.1 \%$ in treated $\mathrm{BaO}$ and $\mathrm{ZnS}$ powder, respectively as compared to control. Hence, these, findings suggest that biofield treatment has altered the structural and physical properties of $\mathrm{BaO}$ and $\mathrm{ZnS}$ powders.
\end{abstract}

Keywords: Biofield treatment; Barium oxide; Zinc sulfide; Particle size; Surface area; Fourier transform infrared spectroscopy

\section{Introduction}

Metal oxides and sulfides are considered as one of interesting class of ceramics due to their versatile applications [1-5]. Zinc sulfide ( $\mathrm{ZnS})$ and barium oxide $(\mathrm{BaO})$ gain attention among the researchers due to their unique optical and electrical properties and wide applications in electrical industries. $\mathrm{ZnS}$ exist as zinc blend structure (wurtzite crystal structure), whereas $\mathrm{BaO}$ exists as rock salt type. Recently, researchers had developed the self-cleaning techniques using barium oxide, in which coal gas provides the power directly to solid oxide fuel cells [6]. This is a cleaner and efficient way to generate electricity from coal reserves. Further, the $\mathrm{BaO}$ is hygroscopic in nature which enables it to use for chemical reactions on anode surface [1]. ZnS possess a particular place due to its application as wide band gap semiconductors, blue light emitting diodes (LEDs), and electroluminescent devices [7-9]. It also become promising material for various other fields such as solar cell, phosphor etc. Currently, there are several methods of producing the metal oxides and sulfides powder such as sol gel chemical bath deposition technique, pulsed-laser deposition vacuum arc deposition and chemical vapor deposition [10-14]. Furthermore, it is well known that electrical, magnetic, and optical properties of ceramics are directly related to its density, crystal structure, crystallite size, and physical parameters [15-17]. After considering the applications and properties of $\mathrm{BaO}$ and $\mathrm{ZnS}$, authors wanted to investigate an alternative and economically viable approach that could be beneficial to modify the physical and structural properties of these powders.

Research converging from many fields of investigation indicates that the human body is a complex energy system. It has been demonstrated that short lived electrical events or action potential exist in several type of mammalian cells such as neurons, muscle cells, and endocrine cells [18]. For instance, the cells present in central nervous system of human body communicate with another by means of electrical signals that travel along the nerve processes. Thus, human has ability to harness the energy from environment or universe and can transmit into any living or nonliving object around the Globe. The object(s) always receive the energy and responds in a useful way that is called biofield energy and this process is termed as biofield treatment. Mr. Trivedi's unique biofield treatment is known as The Trivedi Effect. Mr. Trivedi's biofield treatment has significantly transform the characteristics of various living and non-living things using his biofield treatment. Biofield treatment has substantially altered the atomic, crystalline, physical properties in various metals and ceramics [19-24]. In addition, biofield treatment has also transform the molecular and cellular characteristics microbiology [25-27], biotechnology [28,29], and agriculture [30-32]. In metals and ceramics the biofield treatment has shown the excellent results at physical, thermal, and atomic level. In addition, the biofield treatment had increased the particle size by six fold and enhanced the crystallite size by two fold in zinc powder [19]. Based on the outstanding results achieved by biofield treatment on different materials and considering the industrial significance of $\mathrm{BaO}$ and $\mathrm{ZnS}$, the present study was undertaken to evaluate the impact of biofield treatment on physical and structural properties of $\mathrm{BaO}$ and $\mathrm{ZnS}$.

\section{Experiment}

The $\mathrm{BaO}$ and $\mathrm{ZnS}$ powders used in present experiment were

*Corresponding author: Snehasis J, Trivedi Science Research Laboratory Pvt. Ltd. Hall-A, Chinar Mega Mall, Chinar Fortune City, Hoshangabad Rd., Bhopal-462026, Madhya Pradesh, India, Tel: +91-755-6660006; E-mail: publication@trivedisrl.com

Received July 15, 2015; Accepted August 10, 2015; Published August 12, 2015

Citation: Trivedi MK, Tallapragada RM, Branton A, Trivedi D, Latiyal O, et al (2015) Influence of Biofield Treatment on Physical and Structural Characteristics of Barium Oxide and Zinc Sulfide. J Laser Opt Photonics 2: 122. doi:10.4172/2469410X.1000122

Copyright: (c) 2015 Trivedi MK, et al. This is an open-access article distributed under the terms of the Creative Commons Attribution License, which permits unrestricted use, distribution, and reproduction in any medium, provided the original author and source are credited. 
Citation: Trivedi MK, Tallapragada RM, Branton A, Trivedi D, Latiyal O, et al. (2015) Influence of Biofield Treatment on Physical and Structural Characteristics of Barium Oxide and Zinc Sulfide. J Laser Opt Photonics 2: 122. doi:10.4172/2469-410X.1000122

Page 2 of 7

obtained from Sigma-Aldrich. Each powder samples were divided into two groups, referred as control and treatment. Control group was remained as untreated and treatment group received Mr. Trivedi's biofield treatment.

\section{Biofield treatment}

The treatment group was handed over in sealed pack to Mr. Trivedi for biofield treatment under standard laboratory condition. Mr. Trivedi provided this treatment through his energy transmission process to the treatment group without touching the samples. After that, both control and treated samples were characterized by using X-ray diffraction (XRD), Fourier Transform Infrared Spectroscopy (FTIR) and Surface area analyzer.

\section{X-ray diffraction study}

XRD analysis of control and treated samples were performed using Phillips, Holland PW 1710 XRD diffractometer, which had a copper anode with nickel filter. The wavelength of X-ray radiation used $1.54056 \AA$. Data obtained from the XRD was in chart form of intensity vs. $2 \theta^{\circ}$, with a detailed Table 1 containing d value $(\AA)$, number of peaks, peak width $2 \theta^{\circ}$, peak count, relative intensity of peaks, etc. Further, lattice parameter and unit cell volume were computed using PowderX software. Weight of the unit cell was calculated as, atomic weight multiplied by the number of atoms present in a unit cell. Density of the unit cell was computed as follows:

\section{Density $=\underline{\text { Weight } \text { of unit Cell }}$}

\section{Volume of Unit Cell}

Crystallite size $(\mathrm{G})$ was calculated as follow:

Crystallite size $(\mathrm{G})=\mathrm{k} \lambda / \mathrm{b} \operatorname{Cos} \theta$.

Where, $\lambda$ is the wavelength of X-ray $(=1.54056 \AA)$ and $\mathrm{k}$ is the equipment constant $(=0.94)$.

Besides, the percent change in the lattice parameter was calculated using following equation:

$$
\% \text { Change in lattice parameter }=\frac{\left[\mathrm{A}_{\text {Treated }}-\mathrm{A}_{\text {control }}\right]}{\mathrm{A}_{\text {control }}} \times 100
$$

Where $\mathrm{A}_{\text {Control }}$ and $\mathrm{A}_{\text {Treated }}$ are the lattice parameter of control and treated sample respectively. Similarly, the percent change in all other parameters such as unit cell volume, density, and crystallite size were calculated.

\section{FT-IR analysis}

FT-IR analysis of $\mathrm{BaO}$ and $\mathrm{ZnS}$ samples were performed on Shimadzu, Japan, FT-IR Spectrometer with frequency range of 400-4000/cm.

\begin{tabular}{|l|c|c|c|c|c|c|}
\hline Group & Sample & Control & T1 & T2 & T3 & T4 \\
\hline Lattice & $\mathrm{BaO}$ & 5.545 & 5.521 & 5.521 & 5.522 & 5.527 \\
\cline { 2 - 7 } Parameter $(\AA)$ & $\mathrm{ZnS}$ & 5.403 & 5.403 & 5.407 & 5.403 & 5.393 \\
\hline $\begin{array}{l}\text { Unit Cell Volume } \\
\left(\times 10^{-22} \mathrm{~cm}^{3}\right)\end{array}$ & $\mathrm{BaO}$ & 1.7040 & 1.6830 & 1.6830 & 1.6830 & 1.6880 \\
\cline { 2 - 7 } & $\mathrm{ZnS}$ & 1.5770 & 1.5770 & 1.5800 & 1.5770 & 1.5680 \\
\hline $\begin{array}{l}\text { Density } \\
(\mathrm{g} / \mathrm{cc})\end{array}$ & $\mathrm{BaO}$ & 5.855 & 5.930 & 5.929 & 5.927 & 5.912 \\
\hline $\begin{array}{l}\text { Crystallite } \\
\text { Size }(\mathrm{nm})\end{array}$ & $\mathrm{ZnS}$ & 4.120 & 4.120 & 4.110 & 4.119 & 4.143 \\
\hline & $\mathrm{BaO}$ & 66.5 & 35.9 & 93.4 & 93.4 & 93.4 \\
\hline
\end{tabular}

Table 1: X-ray diffraction analysis of $\mathrm{BaO}$ and $\mathrm{ZnS}$ powder.

\section{Surface area analysis}

The surface area was measured by the Surface area analyzer, Smart SORB 90 based on Brunauer-Emmett-Teller (BET), which had a detection range of $0 \cdot 2-1000 \mathrm{~m}^{2} / \mathrm{g}$. Percent change in surface area was calculated using following equations:

$$
\left[\mathrm{S}_{\text {Treated }}-\mathrm{S}_{\text {control }}\right]
$$

$\%$ Change in surface area $=$ $\times 100$

\section{$S_{\text {control }}$}

Where, $\mathrm{S}_{\text {Control }}$ and $\mathrm{S}_{\text {Treated }}$ are the surface area of control and treated samples respectively.

\section{Results and Discussion}

\section{$\mathrm{X}$-ray diffraction study}

XRD patterns of control and treated $\mathrm{BaO}$ samples are presented in Figures 1a-1e. The XRD pattern exhibited peaks at $2 \theta=13.90^{\circ}, 18.88^{\circ}$, $22.83^{\circ}, 25.58^{\circ}, 26.82^{\circ}, 29.82^{\circ}, 30.83^{\circ}, 34.58^{\circ}$ in control; $19.06^{\circ}, 22.09^{\circ}$, $24.76^{\circ}, 26.16^{\circ}, 26.53^{\circ}, 26.78^{\circ}, 27.97^{\circ}$, and $32.4^{\circ}$ in $\mathrm{T} 1 ; 19.07^{\circ}, 22.10^{\circ}$, $24.78^{\circ}, 26.14^{\circ}, 26.73^{\circ}, 27.98^{\circ}$, and $32.42^{\circ}$ in $\mathrm{T} 2 ; 19.05^{\circ}, 22.06^{\circ}, 24.67^{\circ}$, $26.08^{\circ}, 26.70^{\circ}, 27.91^{\circ}$, and $32.35^{\circ}$ in $\mathrm{T} 3 ; 19.09^{\circ}, 22.09^{\circ}, 24.70^{\circ}, 26.12^{\circ}$, $26.77^{\circ}, 27.91^{\circ}$, and $32.35^{\circ}$ in T4. Further, XRD patterns of control and treated $\mathrm{ZnS}$ samples are presented in Figures 2a-2e. Control sample showed XRD peaks at $2 \theta=28.62^{\circ}, 33.14^{\circ}, 47.58^{\circ}$, and $56.42^{\circ}$. Whereas treated sample showed peaks at $2 \theta=28.61^{\circ}, 33.18^{\circ}, 47.5^{\circ}$, and $56.50^{\circ}$ in

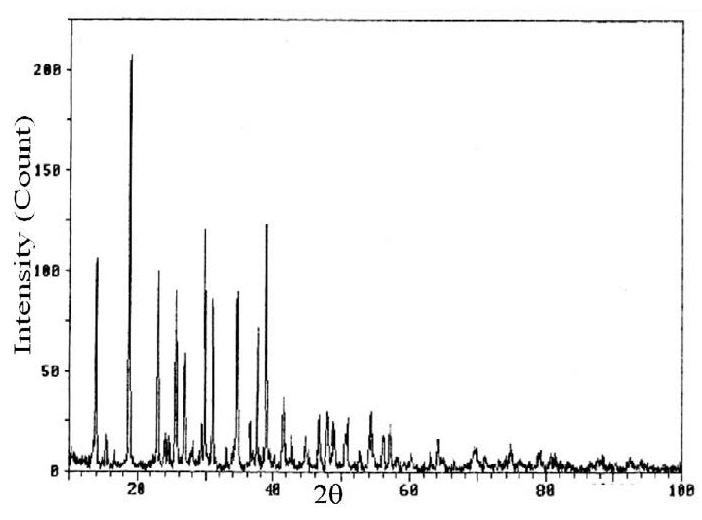

Figure 1a: XRD pattern of control $\mathrm{BaO}$ sample.

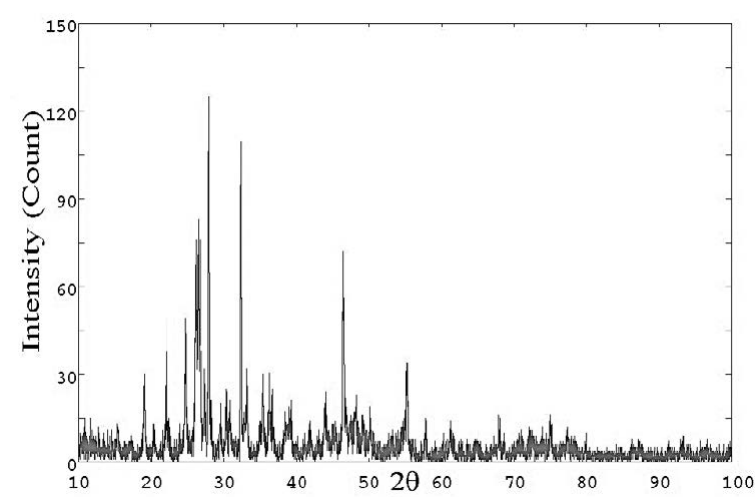

Figure 1b: XRD pattern of biofield treated $\mathrm{BaO}$ sample (T1) 


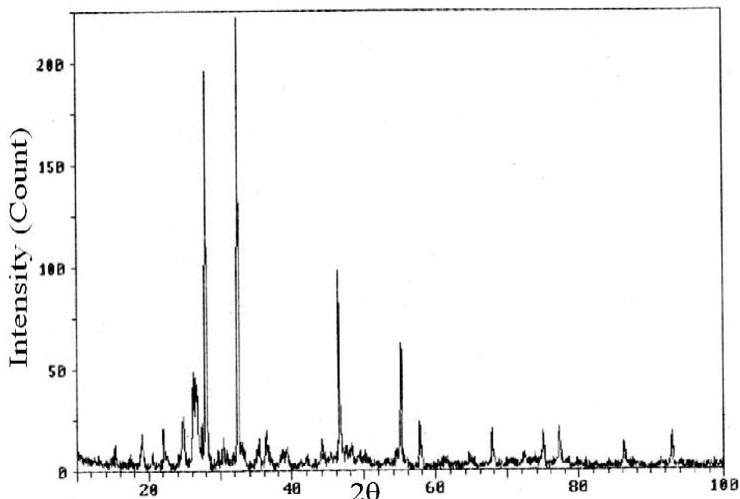

Figure 1c: XRD pattern of biofield treated $\mathrm{BaO}$ sample (T2).

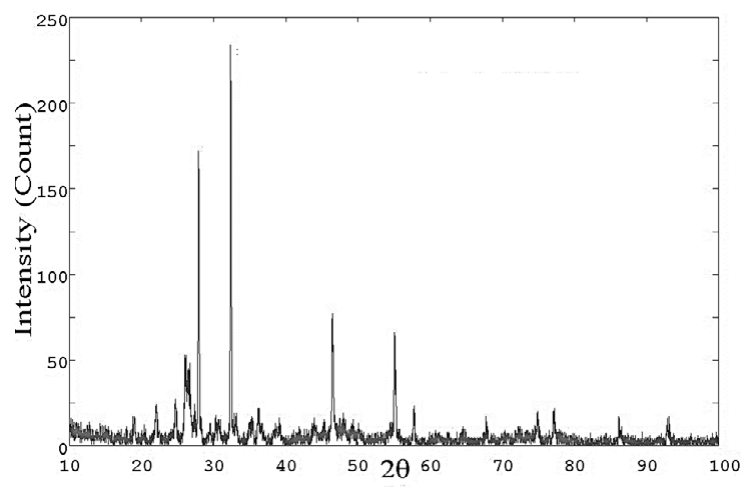

Figure 1d: XRD pattern of biofield treated $\mathrm{BaO}$ sample (T3).

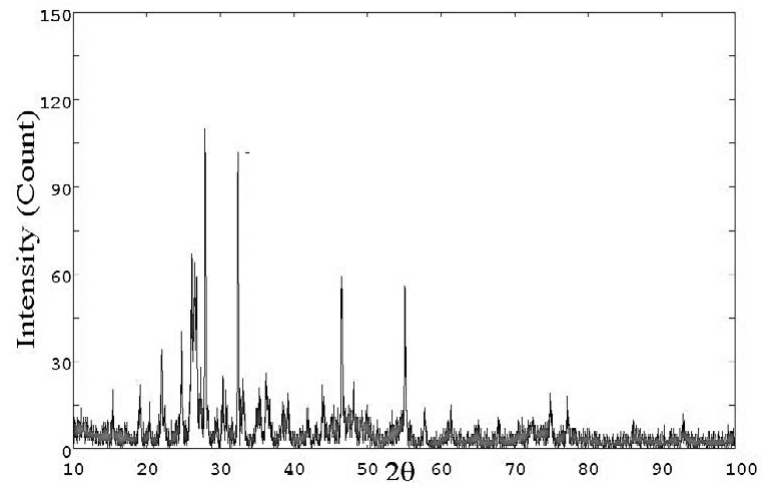

Figure 1e: XRD pattern of biofield treated $\mathrm{BaO}$ sample (T4).

$\mathrm{T} 1 ; 28.62^{\circ}, 33.12^{\circ}, 47.59^{\circ}$, and $56.37^{\circ}$ in $\mathrm{T} 2 ; 28.58^{\circ}, 33.1^{\circ}, 47.58^{\circ}$, and $56.41^{\circ}$ in $\mathrm{T} 3 ; 28.74^{\circ}, 33.25^{\circ}, 47.77^{\circ}$, and $56.50^{\circ}$ in T4. Furthermore, the various parameters of unit cell of $\mathrm{BaO}$ and $\mathrm{ZnS}$ were computed using PowderX software using above XRD peaks, which are presented in Table 1. Moreover, the percent change in lattice parameter; unit cell volume, density, and crystallite size as compared to control are illustrated in Figures 3-6. Data exhibited that the lattice parameter in treated $\mathrm{BaO}$ was significantly reduced by $0.42,0.42,0.41$, and $0.32 \%$ in T1, T2, T3 and T4 respectively, as compared to control (Figure 3). This reduction of lattice parameter led to decrease the unit cell volume

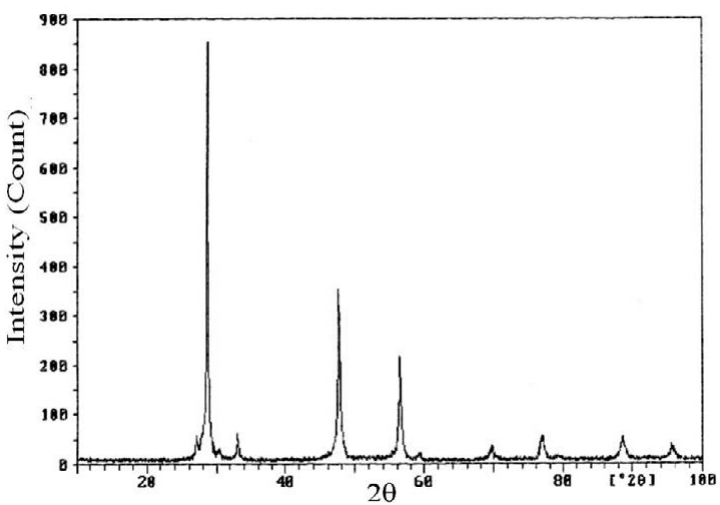

Figure 2a: XRD pattern of control ZnS sample.

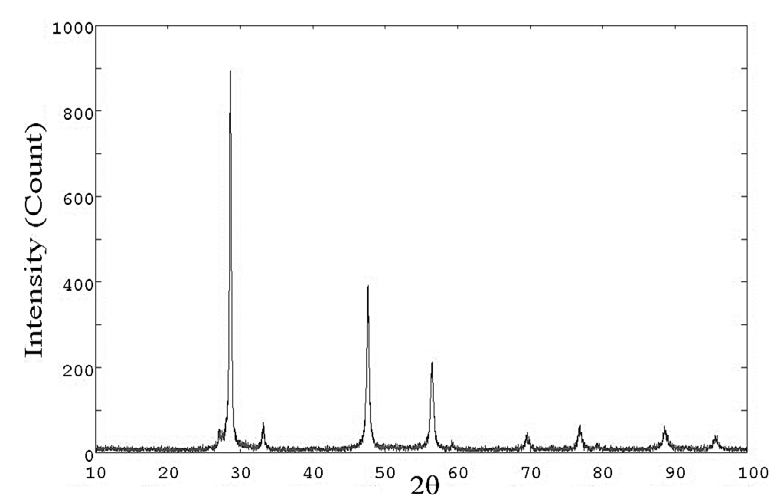

Figure 2b: XRD pattern of biofield treated ZnS sample (T1).

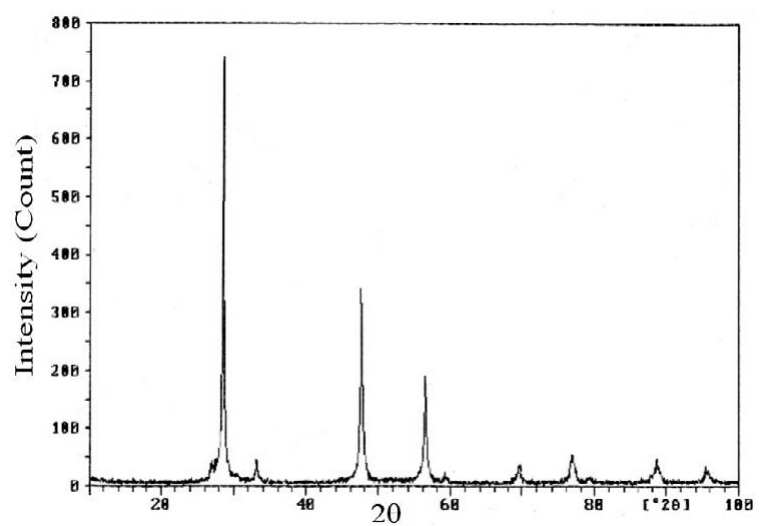

Figure 2c: XRD pattern of biofield treated ZnS sample (T2).

of treated $\mathrm{BaO}$ by $1.26,1.26,1.22$, and $0.98 \%$ in $\mathrm{T} 1, \mathrm{~T} 2, \mathrm{~T} 3$ and $\mathrm{T} 4$ respectively, as compared to control (Figure 4). Furthermore, this reduction in unit cell volume resulted into increase in density by 1.27 , $1.27,1.23$, and $0.98 \%$ in $\mathrm{T} 1, \mathrm{~T} 2, \mathrm{~T} 3$ and $\mathrm{T} 4$ respectively, as compared to control (Figure 5). It is well known fact that the density is inversely proportional to volume of a substance for a given mass. The reduction in volume of unit cell and increase in density suggest that $\mathrm{BaO}$ lattice was contracted after biofield treatment. It is previously reported that internal strain in ceramics can be produced through high temperature, 


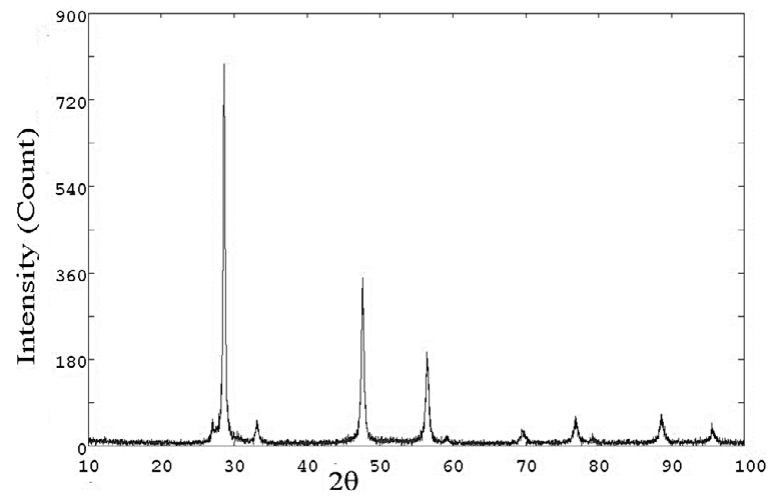

Figure 2d: XRD pattern of biofield treated ZnS sample (T3).

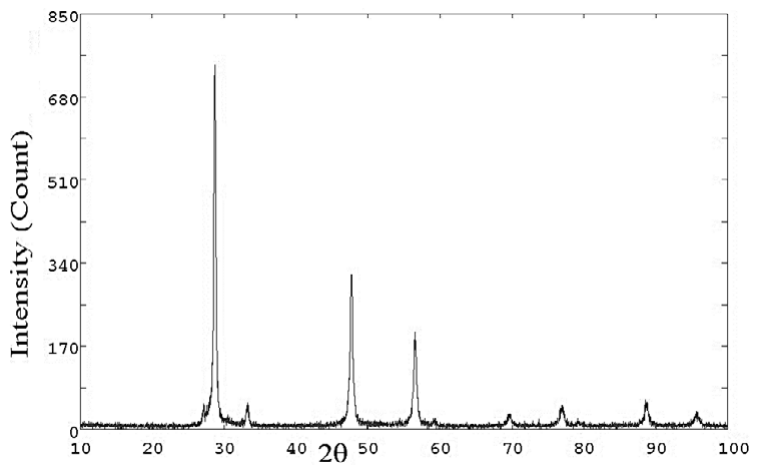

Figure 2e: XRD pattern of biofield treated ZnS sample (T4).

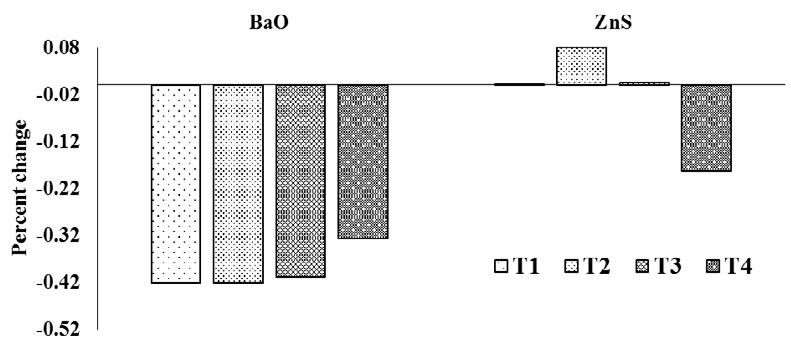

Figure 3: Percent change in lattice parameter in treated $\mathrm{BaO}$ and $\mathrm{ZnS}$ as compared to control.

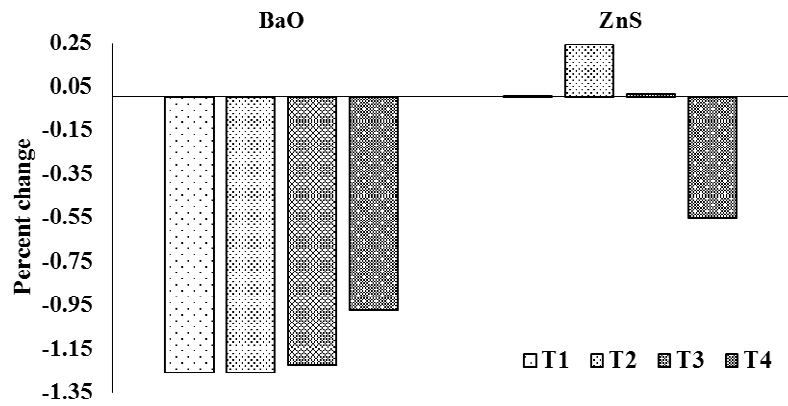

Figure 4: Percent change in unit cell volume in treated $\mathrm{BaO}$ and $\mathrm{ZnS}$ as compared to control. doping, and milling [33,34]. In addition, it is also reported that some material respond to electric and magnetic field in form of strain such as piezoelectric material [35]. Thus, it is hypothesized that biofield treatment might transfer the energy in form of electromagnetic waves, which consist of electric and magnetic field and that field may push the positive barium ion and negative oxygen towards each other. Hence, the movement of both ions toward each other may lead to reduced lattice parameter. XRD data of $\mathrm{ZnS}$ showed that the percent change in lattice parameter was -0.08 and $0.18 \%$ in $\mathrm{T} 2$ and $\mathrm{T} 4$ respectively, whereas no change was found in $\mathrm{T} 1$ and $\mathrm{T} 3$, as compared to control. Percent change in unit cell volume of treated $\mathrm{ZnS}$ was 0.24 and -0.55 in T2 and T4 respectively, as compared to control. This change in unit cell volume led to change the density by -0.24 and $0.552 \%$ in T2 and T4 respectively, as compared to control. These changes in lattice parameter suggest that both kind of stress: compressive and tensile possibly applied through biofield treatment. In addition, result also indicated that the permanent lattice strain probably induced in $\mathrm{BaO}$ and $\mathrm{ZnS}$ crystals through biofield treatment. Furthermore, data exhibited that crystallite size was change from $66.5 \mathrm{~nm}$ (control) to 35.9, 93.4, 93.4, and 93.4 $\mathrm{nm}$ in treated $\mathrm{BaO}$ samples $\mathrm{T} 1, \mathrm{~T} 2, \mathrm{~T} 3$, and T4, respectively. Percent change in crystallite size of treated $\mathrm{BaO}$ was $-46 \%$ in $\mathrm{T} 1$ and $40.5 \%$ in $\mathrm{T} 2, \mathrm{~T} 3$ and T4 as compared to control (Figure 6). This indicates that crystallite size of treated $\mathrm{BaO}$ was increased in three out of four sample tested. Nevertheless, the crystallite size in treated $\mathrm{ZnS}$ was substantially increased from $35.6 \mathrm{~nm}$ (control) to 61, 42.7, 61, and $47.4 \mathrm{~nm}$ in $\mathrm{T} 1, \mathrm{~T} 2, \mathrm{~T} 3$ and $\mathrm{T} 4$ respectively (Table 1 ), as compared to control. It indicates that crystallite size was increased by $71.4,20,71.4$, and $33.4 \%$ in T1, T2, T3 and T4 respectively, as compared to control (Figure 6). Overall data suggest that crystallite size was increased in both $\mathrm{BaO}$ and $\mathrm{ZnS}$ powder after biofield treatment. Similar results of increase in crystallite size in silicon dioxide and antimony had been reported by our group in previous studies [36,37]. Furthermore, it is well known that the crystallite size of ceramics powder increased with increase in

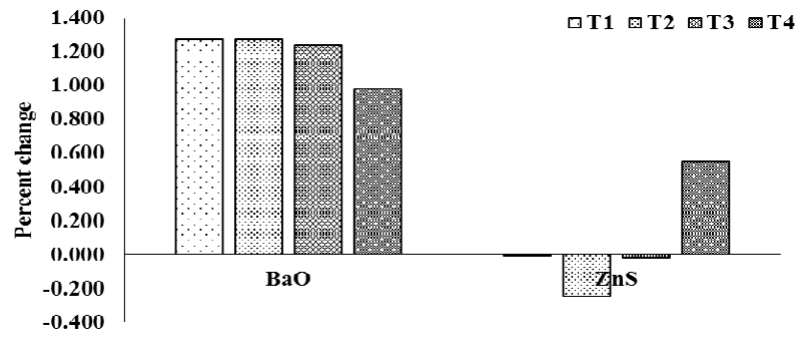

Figure 5: Percent change in density of treated $\mathrm{BaO}$ and $\mathrm{ZnS}$ as compared to control.

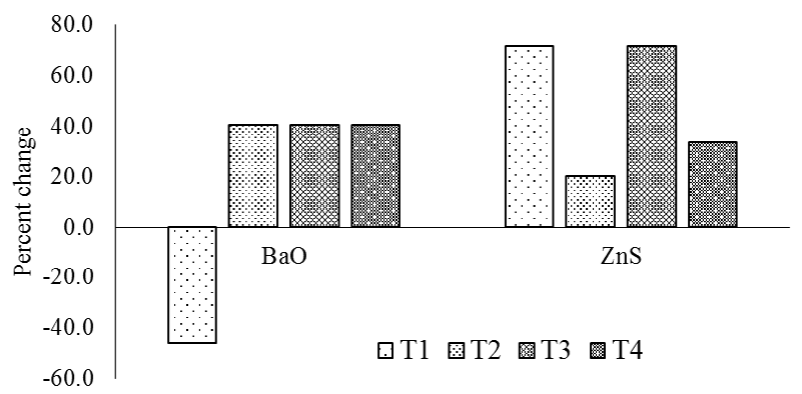

Figure 6: Percent change in crystallite size of treated $\mathrm{BaO}$ and $\mathrm{ZnS}$ as compared to control. 


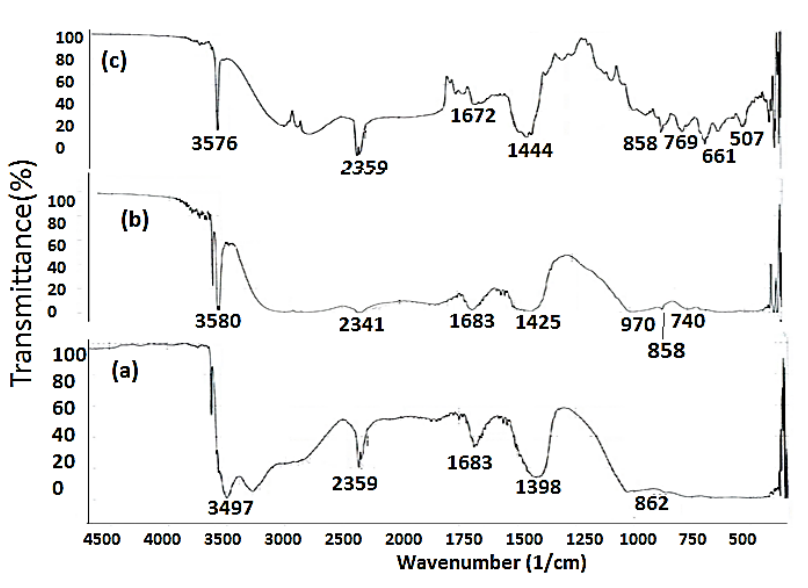

Figure 7: FT-IR spectrum of BaO. (a) Control (b) Treated T1 (c) Treated T2.

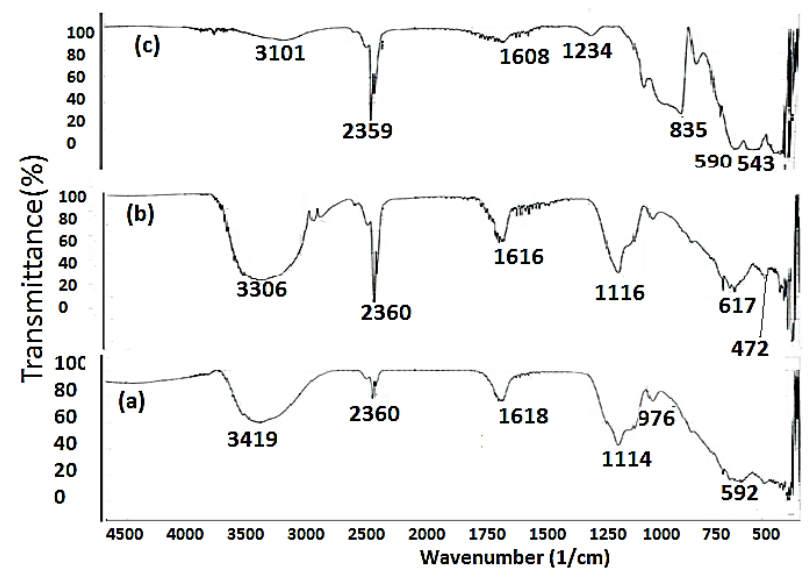

Figure 8: FT-IR spectrum of ZnS (a) Control (b) Treated T1 (c) Treated T2.

temperature [38]. Furthermore, it is assumed that internal strains present in treated powder made dislocations to move unhindered that results into reorient the planes on either side of the crystallite boundaries. Further, this reorientation of neighboring planes into same planes may lead to increase crystallite size. Moreover, it is also reported that alteration in crystallite size in $\mathrm{ZnS}$ leads to change the energy band gap [39]. Hence it is assumed that band gap in treated ZnS sample may be changed after biofield treatment. Moreover, based on the above findings in XRD analysis, control, T1 and T2 were analyzed using FT-IR.

\section{FT-IR analysis}

FT-IR spectra of control and treated $\mathrm{BaO}$ samples are presented in Figure 7. IR spectra showed the peaks at wavenumber 3497, 3580, and $3576 / \mathrm{cm}$ in control, T1, and T2 respectively, which could be due to $\mathrm{O}-\mathrm{H}$ stretching vibrations. Peaks observed at 1683, 1683, and $1672 / \mathrm{cm}$ in control, T1 and T2 respectively can be assigned to O-H bending vibrations. The emergence of peaks corresponding to $\mathrm{O}-\mathrm{H}$ stretching and bending could be due to moisture absorption by $\mathrm{BaO}$ powder. Furthermore, absorption band observed at wavenumber $862 / \mathrm{cm}$ (control), 740-970 $\mathrm{cm}^{-1}$ (T1), and 507, 661, 769, 858/cm (T2) that could be due to Ba-O bonding vibrations [40]. Data suggest that number of peaks and intensity corresponding to $\mathrm{BaO}$ vibration were

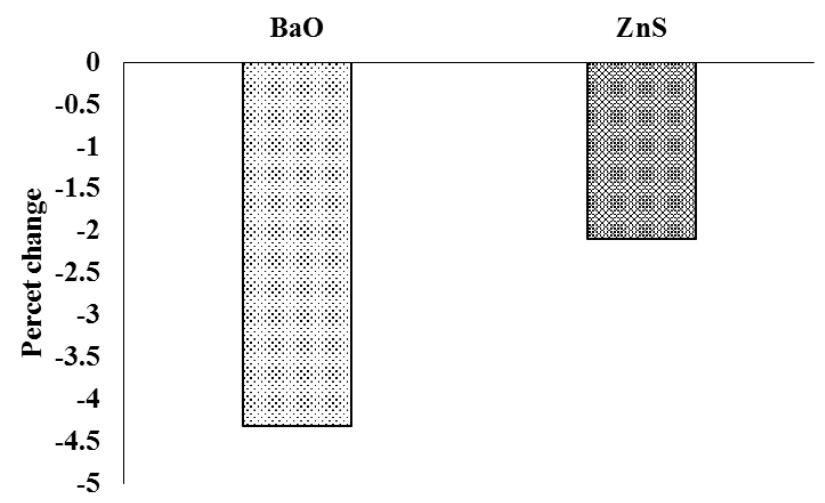

Figure 9: Percent change in surface area of treated $\mathrm{BaO}$ and $\mathrm{ZnS}$ as compared to control.

\begin{tabular}{|c|c|c|}
\hline \multirow{2}{*}{ Group } & \multicolumn{2}{|c|}{ Surface area $\left.\mathbf{( m}^{2} / \mathbf{g}\right)$} \\
\hline & Control & Treated \\
\hline $\mathrm{BaO}$ & 0.48 & 0.45 \\
\hline $\mathrm{ZnS}$ & 15.21 & 14.89 \\
\hline
\end{tabular}

Table 2: Surface area of $\mathrm{BaO}$ and $\mathrm{ZnS}$ powder.

changed in T1 and T2 after biofield treatment. The absorption peaks found at 1398, 1425, and 1444/cm in control, T1, and T2 respectively, could be due to formation of $\mathrm{BaCO}_{3}$ after $\mathrm{CO}_{2}$ absorption by $\mathrm{BaO}$ sample from atmosphere [41]. Besides, IR spectra of $\mathrm{ZnS}$ powder is illustrated in Figure 8, in which absorption peaks observed at 592/ $\mathrm{cm}$ (control), 617/cm (T1) and 590/cm (T2) that were assigned to $\mathrm{Zn}-\mathrm{S}$ stretching vibrations $[42,43]$. It indicates that absorption peaks were changed in treated sample as compared to control, which could be due to alteration in $\mathrm{Zn}-\mathrm{S}$ bond length after biofield treatment. Absorption peaks observed in range of $3000-3500 / \mathrm{cm}$ in control, T1 and $\mathrm{T} 2$ could be due to $\mathrm{O}-\mathrm{H}$ stretching vibrations. The $\mathrm{O}-\mathrm{H}$ bending peaks were observed at 1618, 1616, and $1608 / \mathrm{cm}$ in control, T1 and T2 respectively. The emergence of peaks corresponding to $\mathrm{O}-\mathrm{H}$ stretching and bending could be due to moisture absorption by $\mathrm{ZnS}$ powder. In addition, the peaks observed at wavenumber 1114,1116 , and $1234 / \mathrm{cm}$ in control, T1 and T2, respectively, are possibly the characteristic peaks for $\mathrm{ZnS}$ particles $[44,45]$. Recently, our group reported that the biofield treatment has changed the bond length in ceramic nano oxides $(\mathrm{ZnO}$, $\mathrm{Fe}_{3} \mathrm{O}_{4}$ ) [46]. Thus, based on current data, it is assumed that biofield treatment may alter the bonding properties in $\mathrm{BaO}$ and $\mathrm{ZnS}$, that possibly resulted into alteration in IR peaks in treated as compared to control.

\section{Surface area analysis}

Surface area analysis in term of percent change of $\mathrm{BaO}$ and $\mathrm{ZnS}$ powder are shown in Figure 9. Data showed that the surface area was reduced by $4.32 \%$ and $2.1 \%$ in $\mathrm{BaO}$ and $\mathrm{ZnS}$, respectively as compared to control (Table 2). It is possible that biofield energy transferred through treatment, which might induce energy milling. Due to which $\mathrm{BaO}$ and $\mathrm{ZnS}$ powder particles might be agglomerated after biofield treatment and increased particle size. Further, this increase in particle size probably reduced surface area in treated samples as compared to control.

\section{Conclusion}

Overall, the biofield treatment has significantly altered the physical 
Citation: Trivedi MK, Tallapragada RM, Branton A, Trivedi D, Latiyal O, et al. (2015) Influence of Biofield Treatment on Physical and Structural Characteristics of Barium Oxide and Zinc Sulfide. J Laser Opt Photonics 2: 122. doi:10.4172/2469-410X.1000122

Page 6 of 7

and structural properties of both $\mathrm{BaO}$ and $\mathrm{ZnS}$ samples. XRD result showed that density of treated $\mathrm{BaO}$ and $\mathrm{ZnS}$ powder was increased upto $1.27 \%$ and $0.55 \%$ as compared to control. It could be due to reduction of lattice parameter in unit cell after biofield treatment. In addition, crystallite size was significantly increased by $40.5 \%$ and $71.4 \%$ in $\mathrm{BaO}$ and $\mathrm{ZnS}$, respectively as compared to control. FT-IR data showed the shifting of absorption peaks in treated $\mathrm{BaO}$ and $\mathrm{ZnS}$ corresponding to $\mathrm{Ba}-\mathrm{O}$ and $\mathrm{Zn}-\mathrm{S}$ stretching vibrations, respectively, as compared to control. Thus, it is hypothesized that bond length of $\mathrm{Zn}-\mathrm{S}$ and $\mathrm{Ba}-\mathrm{O}$, possibly altered after biofield treatment. Besides, the surface area was reduced by $4.32 \%$ and $2.1 \%$ in treated $\mathrm{BaO}$ and $\mathrm{ZnS}$ powder, respectively as compared to control. Thus, based on the alteration found in density, crystallite size, surface area, and bond length in treated $\mathrm{BaO}$ and $\mathrm{ZnS}$, it is assumed that biofield treatment could alter the optoelectronics characteristics in ceramics.

\section{Acknowledgement}

We thank Dr. Cheng Dong of NLSC, Institute of Physics, and Chinese academy of Sciences for supporting in using PowderX software for analyzing X-ray Diffraction data. Authors also would like to thank Trivedi science, Trivedi master wellness and Trivedi testimonials for their support during the work.

\section{References}

1. Umar EA, Hahn YB (2009) Metal oxide nanostructures and their applications. American Scientific Publishers.

2. Baraton MI (2003) Synthesis, functionalization and surface treatment of nanoparticles. American Scientific Publishers

3. Beek WJE, Wienk MM, Emerink MK, Yang X, Janssen RAJ (2005) Hybrid zinc oxide conjugated polymer bulk heterojunction solar cells. J Phys Chem B 109: 9505-9516.

4. Manzoor U, Kim DK (2006) Synthesis and enhancement of ultraviolet emission by post-thermal treatment of unique zinc oxide comb-shaped dendritic nanostructures. Scripta Materialia 54: 807-811.

5. Wang X, Lee BI, Hu MZ, Payzant EA, Blom DA (2003) Synthesis of nanocrystalline BaTiO3 by solvent refluxing method. J Mater Sci Lett 22: 557559.

6. Ahmad N, Wahab R, and Alam M (2014) Facile growth of barium oxide nanorods: Structural and optical properties. J Nanosci Nanotechnol 14: 53425346.

7. Hwang JM, Oh MO, Kim I, Lee JK, Ha CS (2005) Preparation and characterization of ZnS based nano-crystalline particles for polymer lightemitting diodes. Curr Appl Phys 5: 31-34.

8. Friend $\mathrm{RH}$ (2001) Conjugated polymers. New materials for optoelectronic devices. Pure and Appl Chem 73: 425-430.

9. Bhargava RN, Gallagher D, Hong X, Nurmikko A (1994) Optical properties of manganese-doped nanocrystals of ZnS. Phys Rev Lett 72: 416-419.

10. Gesheva K, Cziraki A, Ivanova T, Szekeres A (2005) Thin Solid Films, Structure and composition of thermally annealed Mo- and W-based CVD metal oxide thin films. Thin Solid Films 492: 322-326

11. Ohkubo I, Christen HM, Khalifah P, Sathyamurthy S, Zhai HY, et al. (2004) Continuous composition-spread thin films of transition metal oxides by pulsed laser deposition. Appl Surf Sci 223: 35-38.

12. Kandalkar SG, Gunjakar JL, Lokhande CD, Joo OS (2009) Synthesis of cobalt oxide interconnected flacks and nano-worms structures using low temperature chemical bath deposition. J Alloys Comp 478: 594-598.

13. Dhawale DS, More AM, Latthe SS, Rajpure KY, Lokhande CD (2008) Room temperature synthesis and characterization of $\mathrm{CdO}$ nanowires by chemica bath deposition (CBD) method. Appl Surf Sci 254: 3269-3273.

14. Kumar RS, Sudhagar $P$, Sathyamoorthy R, Matheswaran P, Kang YS (2009) Direct assembly of $\mathrm{ZnO}$ nanostructures on glass substrates by chemical bath deposition through precipitation method. Superlatt Microstruct 46: 917-924

15. Borah JP, Barman J, Sarma KC (2008) Structural and optical properties of ZnS nanoparticles. Chalcogenide Lett 5: 201- 208.
16. Uzar N, Arikan MC (2011) Synthesis and investigation of optical properties of ZnS nanostructures. Bull Mater Sci 34: 287-292.

17. Al- Rasoul KT, Abbas NK, Shanan ZJ (2013) Structural and optica characterization of $\mathrm{Cu}$ and $\mathrm{Ni}$ doped $\mathrm{ZnS}$ nanoparticles. Int J Electrochem Sci 8: $5594-5604$.

18. Movaffaghi Z, Farsi M (2009) Biofield therapies: Biophysical basis and biological regulations. Complement Ther Clin Pract 15: 35-37.

19. Trivedi MK, Tallapragada RM (2008) A transcendental to changing metal powder characteristics. Met Powder Rep 63: 22-28.

20. Trivedi MK, Tallapragada RM (2009) Effect of superconsciousness external energy on atomic, crystalline and powder characteristics of carbon allotrope powders. Mater Res Innov 13: 473-480.

21. Trivedi MK, Patil S, Tallapragada RM (2012) Thought intervention through bio field changing metal powder characteristics experiments on powder characteristics at a PM plant. Future Control and Automation LNEE 173: 247252.

22. Trivedi MK, Patil S, Tallapragada RM (2013) Effect of biofield treatment on the physical and thermal characteristics of silicon, tin and lead powders. J Material Sci Eng 2: 125.

23. Trivedi MK, Patil S, Tallapragada RM (2013) Effect of biofield treatment on the physical and thermal characteristics of vanadium pentoxide powder. $\mathrm{J}$ Materia Sci Eng S11: 001.

24. Trivedi MK, Patil S, Tallapragada RM (2015) Effect of biofield treatment on the physical and thermal characteristics of aluminium powders. Ind Eng Manage 4: 151.

25. Trivedi MK, Patil S, Bhardwaj $Y$ (2008) Impact of an external energy on Staphylococcus epidermis [ATCC -13518] in relation to antibiotic susceptibility and biochemical reactions - An experimental study. J Accord Integr Med 4: 230-235.

26. Trivedi MK, Patil S (2008) Impact of an external energy on Yersinia enterocolitica [ATCC -23715$]$ in relation to antibiotic susceptibility and biochemical reactions: An experimental study. Internet J Alternat Med 6:2

27. Trivedi MK, Patil S, Bhardwaj Y (2009) Impact of an external energy on Enterococcus faecalis [ATCC - 51299] in relation to antibiotic susceptibility and biochemical reactions - An experimental study. J Accord Integr Med 5 $119-130$.

28. Patil S, Nayak GB, Barve SS, Tembe RP, Khan RR (2012) Impact of biofield treatment on growth and anatomical characteristics of Pogostemon cablin (Benth.). Biotechnology 11: 154-162.

29. Nayak G, Altekar N (2015) Effect of biofield treatment on plant growth and adaptation. J Environ Health Sci 1: 1-9.

30. Shinde V, Sances F, Patil S, Spence A (2012) Impact of biofield treatment on growth and yield of lettuce and tomato. Aust J Basic Appl Sci 6: 100-105.

31. Lenssen AW (2013) Biofield and fungicide seed treatment influences on soybean productivity, seed quality and weed community. Agricultural Journal 8: 138-143.

32. Sances F, Flora E, Patil S, Spence A, Shinde V (2013) Impact of biofield treatment on ginseng and organic blueberry yield. Agrivita J Agric Sci 35.

33. Zorko A, Pregelj M, Gomilsek M, Jaglicic Z, Pajic D, et al. (2015) Strain-induced extrinsic high-temperature ferromagnetism in the Fe-doped hexagonal barium titanate. Sci Rep 5: 7703.

34. Tan K, Johan MR, Ahmad R, Kadri NA, Zain NM, et al. (2012) Mechanica analysis of the effects of different mechanical alloying periods on Ni3Al intermetallic compound fabrication quality. Int J Electrochem Sci 7: 3765-3772.

35. Ren X (2004) Large electric-field-induced strain in ferroelectric crystals by point-defect-mediated reversible domain switching. Nat Mater 3: 91-94.

36. Dhabade VV, Tallapragada RM, Trivedi MK (2009) Effect of external energy on atomic, crystalline and powder characteristics of antimony and bismuth powders. Bull Mater Sci 32: 471-479.

37. Trivedi MK, Patil S, Tallapragada RM (2014) Atomic, crystalline and powder characteristics of treated zirconia and silica powders. J Material Sci Eng 3: 144

38. Hartono A, Satira S, Djamal M, Ramli R, Bahar H, et al. (2013) Effect of 
Citation: Trivedi MK, Tallapragada RM, Branton A, Trivedi D, Latiyal O, et al. (2015) Influence of Biofield Treatment on Physical and Structural Characteristics of Barium Oxide and Zinc Sulfide. J Laser Opt Photonics 2: 122. doi:10.4172/2469-410X.1000122

mechanical treatment temperature on electrical properties and crystallite size of PVDF Film. Adv Mater Phys Chem 3: 71-76

39. Pawar RP (2013) Structural and optical properties of chemically synthesized ZnS nanoparticals. Orient J Chem 29: 1139-1142.

40. Mevada KC, Patel VD, Patel KR (2012) FT-IR, XRD and thermal studies of gelgrown barium tartrate crystals. Arch Phy Res 3: 258-263.

41. Roedel E, Urakawa A, Kureti S, Baiker A (2008) On the local sensitivity of different IR techniques: Ba species relevant in NOx storage-reduction. Phys Chem Chem Phys 10: 6190-6198.

42. Cholan S, Shanmugam N, Kannadasan N, Sathishkumar K, Deivam K (20014) Effect of poly ethylene glycol (PEG) as surfactant on cerium doped ZnS nanoparticles. J Mater Res Technol 3: 222-227.
43. Kumar S, Jeon HC, Kang TW, Singh R, Sharma JK, et al. (2015) Structural and optical properties of silica capped ZnS:Mn quantum dots. J Mater Sci Mater Electron 26: 3939-3946.

44. Ganguly S, Das S, Ghosh S, Dastidar (2013) Distinct antimicrobial effects of synthesized ZnS nanoparticles against twelve pathogenic bacterial strains. Open Sci Repos Chem e70081948.

45. Wang M, Zhang Q, Hao W, Sun ZX (2011) Surface stoichiometry of zinc sulfide and its effect on the adsorption behaviors of xanthate. Chem Central J 5: 73.

46. Trivedi MK, Nayak G, Patil S, Tallapragada RM, Latiyal O (2015) Studies of the atomic and crystalline characteristics of ceramic oxide nano powders after bio field treatment. Ind Eng Manage 4: 161. 